\title{
Streptomyces atriruber sp. nov. and Streptomyces silaceus sp. nov., two novel species of equine origin
}

\author{
Correspondence \\ David P. Labeda \\ David.Labeda@ars.usda.gov
}

\author{
D. P. Labeda, ${ }^{1}$ N. P. Price, ${ }^{2}$ R. M. Kroppenstedt, ${ }^{3}$ J. M. Donahue, ${ }^{4}$ \\ N. M. Williams ${ }^{4}$ and S. F. Sells ${ }^{4}$
}
${ }^{1}$ Microbial Genomics and Bioprocessing Research Unit, National Center for Agricultural Utilization Research, USDA-Agricultural Research Service, Peoria, IL 61604, USA
${ }^{2}$ Bioproducts and Biocatalysis Research Unit, National Center for Agricultural Utilization Research, USDA-Agricultural Research Service, Peoria, IL 61604, USA
${ }^{3}$ DSMZ-German Collection of Microorganisms and Cell Cultures, Inhoffenstraße 7B, Braunschweig, Germany
${ }^{4}$ Livestock Disease Diagnostic Center, Department of Veterinary Science, University of Kentucky, Lexington, KY 40511, USA

\begin{abstract}
Two actinomycete strains, NRRL B-24165 ${ }^{\top}$ and NRRL B- $24166^{\top}$, isolated from lesions on equine placentas in Kentucky, USA, were analysed using a polyphasic taxonomic approach. On the basis of phylogenetic analysis of 16S rRNA gene sequences, morphological observations and the presence of LL-diaminopimelic acid as the diagnostic diamino acid in whole-cell hydrolysates, the new isolates clearly belonged to the genus Streptomyces. Analyses of the phylogenetic positions of strains NRRL B-24165 ${ }^{\top}$ and NRRL B-24166 ${ }^{\top}$ based on $16 S$ rRNA gene sequences of all recognized species of the genus Streptomyces, as well as evaluation of morphological and physiological characteristics, demonstrated that the new isolates could be differentiated from all recognized species and therefore represented novel species. It is proposed that the new strains represent two novel species for which the names Streptomyces atriruber sp. nov. (type strain NRRL B-24165 ${ }^{\top}=$ DSM $41860^{\top}=$ LDDC $6330-99^{\top}$ ) and Streptomyces silaceus sp. nov. (NRRL $\mathrm{B}-24166^{\top}=\mathrm{DSM} 41861^{\top}=$ LDDC $\left.6638-99^{\top}\right)$ are proposed. The species names are based on the distinctive colours of the substrate mycelium of these strains, dark red and deep orange-yellow, respectively.
\end{abstract}

In the course of studies of nocardioform placentitis in thoroughbred mares in Kentucky, USA, a distinctive type of placentitis has been noticed. Lesions, from which Grampositive branching micro-organisms can be cultured, occur on the chorionic surface of the placenta (Donahue \& Williams, 2000; Giles et al., 1993; Hong et al., 1993) and several actinomycetes were isolated from such lesions. These isolates were not identified as Crossiella equi (Donahue et al., 2002) or various Amycolatopsis species

Abbreviation: MALDI-TOF, matrix-assisted laser desorption/ionization time-of-flight.

The GenBank/EMBL/DDBJ accession numbers for the 16S rRNA gene sequences of strains NRRL B-24165 ${ }^{\top}$, NRRL B-24166 ${ }^{\top}$, NRRL B-24676 and NRRL B-24679 are EU812169, EU812170, FJ169329 and FJ169330, respectively.

The MALDI-TOF MS ion profiles for strains NRRL B- $24165^{\top}$, NRRL B-24676 and NRRL B-24679 are available as a supplementary figure. A supplementary table detailing the morphological characteristics of strains NRRL B-24165 ${ }^{\top}$ and NRRL B- $24166^{\top}$ when grown on different ISP media compared with those of related taxa is also available with the online version of this paper.
(Labeda et al., 2003), micro-organisms that are usually implicated in placentitis. The sequences of the 16S rRNA genes of the new isolates, NRRL B-24165 ${ }^{\mathrm{T}}$ (=LDDC 6330$99^{\mathrm{T}}$ ) and NRRL B-24166 ${ }^{\mathrm{T}}$ (=LDDC $\left.6638-99^{\mathrm{T}}\right)$ were determined and found to be related to species of the genus Streptomyces based on BLAST searches (Altschul et al., 1997) against public sequence databases. A study using a polyphasic approach was conducted to clarify the taxonomic position of the novel isolates.

The novel strains were routinely cultivated on yeast extractmalt extract agar (Shirling \& Gottlieb, 1966) at $28{ }^{\circ} \mathrm{C}$. Morphological observations were made using the media of Shirling \& Gottlieb (1966). Scanning electron microscopy was performed using a JEOL model JSM-4200 microscope on osmium tetroxide-fixed, dehydrated, critical pointdried and sputter-coated colonial growth. The gross morphological properties of strains NRRL B-24165 ${ }^{\mathrm{T}}$ and NRRL B-24166 ${ }^{\mathrm{T}}$ on the media studied were quite different and are summarized in Table 1. Both strains produced smooth-surfaced, almost cylindrical spores in straight to 
Table 1. Differential morphological and physiological properties that distinguish strains NRRL B-24165 ${ }^{\top}$ and $N R R L B-24166^{\top}$ from the nearest phylogenetic species

Strains: 1, NRRL B-24165 ${ }^{\mathrm{T}}$; 2, S. avermitilis NCIMB $12804^{\mathrm{T}}$ (some data taken from Kim \& Goodfellow, 2002); 3, NRRL B-24166 ${ }^{\mathrm{T}}$; 4 , S. aureoverticillatus NRRL B-3326 ${ }^{\mathrm{T}}$. +, Positive; -, negative; w, weak reaction; ND, not determined. All strains showed a smooth spore surface.

\begin{tabular}{|c|c|c|c|c|}
\hline Characteristic & 1 & 2 & 3 & 4 \\
\hline \multicolumn{5}{|l|}{ Morphology and pigmentation } \\
\hline Colour of vegetative mycelium (ISP 2) & $\begin{array}{l}\text { Greyish-reddish } \\
\text { brown }\end{array}$ & $\begin{array}{c}\text { Yellowish brown to medium } \\
\text { yellowish brown }\end{array}$ & $\begin{array}{l}\text { Medium yellowish } \\
\text { brown }\end{array}$ & Strong red \\
\hline Colour of spore mass & Light grey & Grey & $\begin{array}{c}\text { White to yellowish } \\
\text { white }\end{array}$ & $\begin{array}{l}\text { Pale yellow to } \\
\text { pale cinnamon }\end{array}$ \\
\hline Sporophore morphology & Flexuous & Spiral & Flexuous & Spiral \\
\hline Melanin pigment on peptone-iron agar & - & + & - & - \\
\hline Soluble pigments & Dark red & Brown & None & None \\
\hline \multicolumn{5}{|l|}{ Degradation of: } \\
\hline Tyrosine & + & - & + & - \\
\hline \multicolumn{5}{|l|}{ Growth on sole carbon sources $(0.1 \%, \mathrm{w} / \mathrm{v})$} \\
\hline Adonitol & + & - & + & ND \\
\hline L-Arabinose & + & + & - & + \\
\hline myo-Inositol & + & + & - & + \\
\hline Maltose & - & + & w & ND \\
\hline L-Rhamnose & + & + & - & + \\
\hline Sucrose & $\mathrm{w}$ & - & $\mathrm{w}$ & + \\
\hline D-Xylose & + & + & - & $\mathrm{w}$ \\
\hline \multicolumn{5}{|l|}{ Growth in the presence of: } \\
\hline $9 \% \mathrm{NaCl}$ & + & - & + & - \\
\hline
\end{tabular}

flexuous chains, as can be seen in the scanning electron micrographs (Fig. 1).

The isomer of diaminopimelic acid present was determined using TLC of cell hydrolysates according to the method of Hasegawa et al. (1983). Both strains were found to contain the LL-isomer, which is typical of members of the genus Streptomyces.

Genomic DNA for sequencing of the 16S rRNA genes was isolated from growth on DSMZ Medium No. 554 (DSMZ, 2001) plates using UltraClean microbial DNA isolation kits (Mo Bio Laboratories). The DNA was amplified, and sequenced following previously described procedures (Labeda \& Kroppenstedt, 2000). The identification of phylogenetic neighbours was initially carried out by the BLAST (Altschul et al., 1997) and FASTA (Pearson \& Lipman, 1988) programs against the GenBank sequence database as well as the EzTaxon database of type strains of recognized prokaryotic names (Chun et al., 2007) and similar results were obtained. The 20 sequences with the highest scores in EzTaxon were then selected for the calculation of pairwise sequence similarity using the global alignment algorithm, which was implemented at the EzTaxon server (http:// www.EzTaxon.org/; Chun et al., 2007). The sequences were aligned against sequences for taxa in the family Streptomycetaceae selected on the basis of the aforementioned search within ARB (Ludwig et al., 2004) and data were exported for use in MEGA version 4 (Tamura et al., 2007). Phylogenetic trees were constructed using the
Kimura two-parameter distance calculation (Kimura, 1980) and the neighbour-joining method of Saitou \& Nei (1987). The minimum evolution (Rzhetsky \& Nei, 1992) and maximum-parsimony (Eck \& Dayhoff, 1966; Fitch, 1971; Kumar et al., 1993; Nei \& Kumar, 2000) methods in MEGA were also used to determine whether alternate phylogenetic algorithms supported the neighbour-joining phylogenetic tree.

The closest taxon to strain NRRL B-24165 ${ }^{\mathrm{T}}$ in the EzTaxon similarity searches was found to be Streptomyces avermitilis NCIMB $12804^{\mathrm{T}}$ (GenBank accession no. AF145223), whose sequence was $98.58 \%$ similar but differed in 21 nucleotide positions. The relationship of strain NRRL B-24165 ${ }^{\mathrm{T}}$ to the phylogenetically nearest taxa and, in particular, S. avermitilis NCIMB $12804^{\mathrm{T}}$, can be seen in the phylogenetic tree shown in Fig. 2a. Note that this phylogenetic relationship was supported by all of the computational methods used.

The closest taxa to strain NRRL B-24166 ${ }^{\mathrm{T}}$ in the EzTaxon similarity searches were found to be Streptomyces aureoverticillatus NRRL B-3326 ${ }^{\mathrm{T}}$ (AY999774) and Streptomyces gougerotii DSM $40324^{\mathrm{T}}$ (Z76687), whose sequences were $98.85 \%$ similar but differed in 17 nucleotide positions. The relationship of strain NRRL B-24166 ${ }^{\mathrm{T}}$ to the phylogenetically nearest taxa and, in particular, $S$. aureoverticillatus NRRL B- $3326^{\mathrm{T}}$ and S. gougerotii DSM $40324^{\mathrm{T}}$, can be seen in the phylogenetic tree shown in Fig. $2 \mathrm{~b}$.

Physiological tests, including production of acid from carbohydrates, utilization of organic acids and hydrolysis 


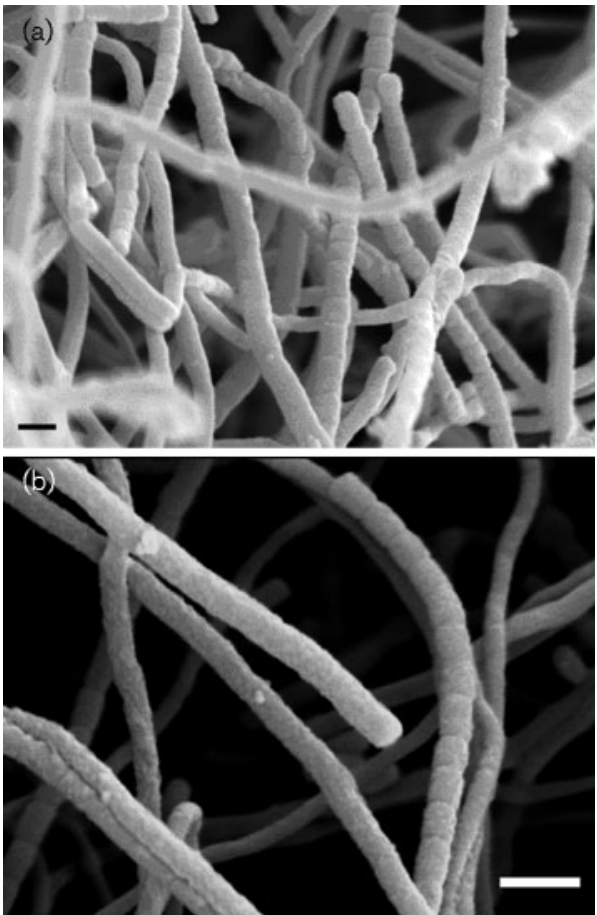

Fig. 1. Scanning electron micrographs of 21 day growth of (a) strain NRRL B-24165 ${ }^{\top}$ and (b) strain NRRL B-24166 ${ }^{\top}$ on glycerol-asparagine medium (ISP 5). Note that both strains produce straight to slightly flexuous chains of almost cylindrical, smooth-surfaced spores. Bars, $1 \mu \mathrm{m}$.

and decomposition of adenine, guanine, hypoxanthine, tyrosine, xanthine, casein, aesculin, urea and hippurate, were evaluated using the media of Gordon et al. (1974). Phosphatase activity was evaluated by using the method of Kurup \& Schmitt (1973). The temperature range for growth was determined on slants of DSMZ Medium No. 554.

Strain NRRL B-24165 ${ }^{\mathrm{T}}$ could be easily differentiated from S. avermitilis, its nearest phylogenetic neighbour, based on sporophore morphology, gross morphological characteristics and a number of physiological characteristics as can be seen in Table 1. Similarly, strain NRRL B-24166 ${ }^{\mathrm{T}}$ could also be distinguished from the nearest phylogenetically related species, S. aureoverticillatus, based on sporophore morphology, gross morphological characteristics and a number of physiological characteristics. The morphological characteristics of strains NRRL B- $24165^{\mathrm{T}}$ and NRRL B-24166 ${ }^{\mathrm{T}}$ when grown on ISP 2, ISP 3 , ISP 4 and ISP 5 media were compared with those of their nearest phylogenetic neighbours (see Supplementary Table S1 in IJSEM Online). It is not surprising that both of these strains grew quite well at $37{ }^{\circ} \mathrm{C}$, reflecting the environment, equine placentas, from which they were originally isolated.

Although both novel isolates showed relatively high (i.e. $>98 \%$ ) $16 \mathrm{~S}$ rRNA gene sequence similarity with other recognized species of the genus Streptomyces, we feel that the proposal of Stackebrandt \& Ebers (2006), suggesting DNA-DNA relatedness determinations are not necessary unless the $16 \mathrm{~S}$ rRNA sequence similarity is greater than 98.7-99\%, should serve as the guideline for members of this genus, given the high 16S rRNA gene sequence similarity shared among most species. Both novel strains could be clearly differentiated from other recognized species and two additional isolates, NRRL B-24676 (=LDDC 60788-07) and NRRL B-24679 (=LDDC 327808 ), were obtained from equine placentas during the 2007 and 2008 foaling seasons, respectively. The almost complete 16S rRNA gene sequences were determined for these strains (FJ169329 and FJ169330, respectively) and were found to have identical (99.9-100\%) 16 S rRNA gene sequences as well as a similar gross morphology to strain NRRL B- $24165^{\mathrm{T}}$, which was originally isolated in 1999 . To confirm that the two recent isolates were identical to strain NRRL B-24165 ${ }^{\mathrm{T}}$, the three strains were grown for 7 days on yeast extract-malt extract agar and colonies were analysed by matrix-assisted laser desorption/ionization time-offlight mass spectrometry (MALDI-TOF MS) of intact cells using an Omniflex MALDI-TOF mass spectrometer (Bruker Daltonic) run in reflectron mode as described previously (Tamura et al., 2008). The spectra of the three strains were found to be identical (see Supplementary Fig. S1 in IJSEM Online), confirming that the two additional strains belonged to the same species as strain NRRL B- $24165^{\mathrm{T}}$.

The phylogenetic, morphological and physiological data are sufficient to differentiate strains NRRL B-24165 ${ }^{\mathrm{T}}$ and NRRL B-24166 ${ }^{\mathrm{T}}$ from all recognized species within the genus Streptomyces and we propose the names Streptomyces atriruber sp. nov. for strain NRRL B-24165 ${ }^{\mathrm{T}}$ and Streptomyces silaceus sp. nov. for strain NRRL B-24166 ${ }^{\mathrm{T}}$, respectively. The detailed morphological and physiological characteristics of the novel species are provided below.

\section{Description of Streptomyces atriruber sp. nov.}

Streptomyces atriruber (a.tri.ru'ber. L. adj. ater -tra -trum black, dark; L. adj. ruber -bra -brum red; N.L. masc. adj. atriruber blackish-red, referring to the colour of the substrate mycelium and soluble pigments).

Substrate mycelium is very dark red in colour. Aerial mycelium is white to pinkish white and the spore mass, where produced, is light grey. Dark red to reddish purple soluble pigments are produced on most media. Spores are borne on flexuous aerial hyphae (Rectiflexibiles) and are ovoid to cylindrical $(0.6-0.7 \times 0.6-1.1 \mu \mathrm{m})$ and have a smooth surface. Melanin pigments are not produced. Adenine, casein, aesculin, gelatin, hypoxanthine, starch, tyrosine, urea and xanthine are hydrolysed, but allantoin is not. Nitrate reductase is produced; phosphatase is not produced. Acid is produced on adonitol, L-arabinose, cellobiose, dextrin, D-fructose, galactose, glucose, glycerol, D-mannose, melibiose, raffinose, L-rhamnose, salicin and trehalose, but not on dulcitol, erythritol, inositol, D-lactose, 
(a) $\underline{0.001}$

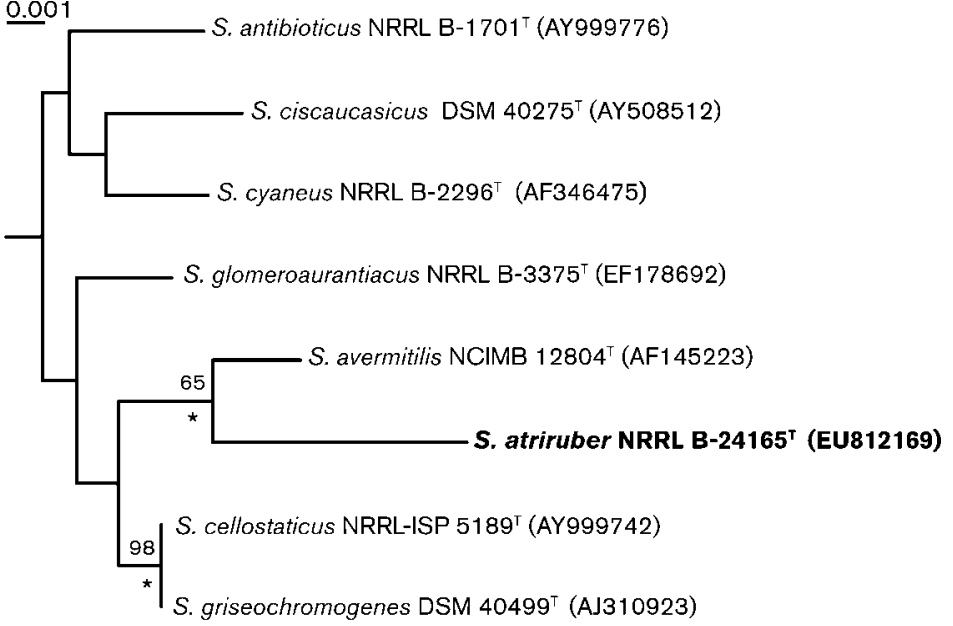

(b)

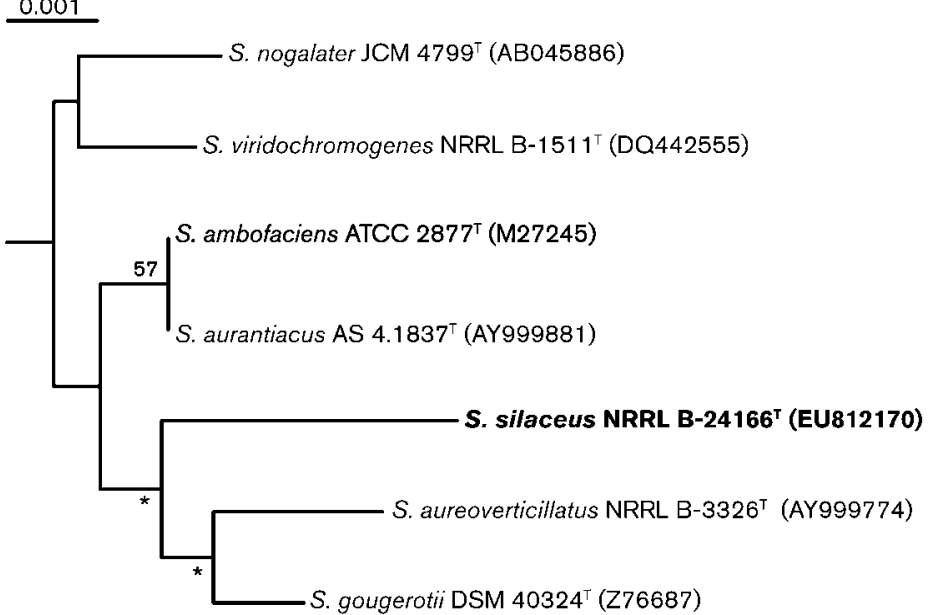

Fig. 2. Phylogenetic subtree for a selected set of taxa of the genus Streptomyces calculated with MEGA4 (Tamura et al., 2007) from almost complete 16S rRNA gene sequences using Kimura's evolutionary distance method (Kimura, 1980) and the neighbour-joining method of Saitou \& Nei (1987) illustrating the taxonomic position of (a) strain NRRL $\mathrm{B}-24165^{\top}$ and (b) strain NRRL B-24166 ${ }^{\top}$ relative to species found to be most similar from BLAST searches (Altschul et al., 1997). Percentages at the nodes represent levels of bootstrap support from 100 resampled datasets; values $<50 \%$ are not shown. Asterisks indicate that the corresponding branches were also recovered in the minimum-evolution (Rzhetsky \& Nei, 1992) and maximum-parsimony (Eck \& Dayhoff, 1966; Fitch, 1971; Kumar et al., 1993; Nei \& Kumar, 2000) trees. Bars, 0.001 nucleotide substitutions per site.

maltose, melezitose, methyl $\beta$-xyloside, sorbitol or xylose. Weak acid production on mannitol and methyl $\alpha$-Dglucoside. Grows on adonitol, L-arabinose, cellobiose, dextrin, D-fructose, galactose, glucose, inositol, mannitol, D-mannose, melibiose, raffinose, L-rhamnose, salicin, trehalose and xylose as sole carbon sources and weak growth on sucrose, but no growth on inulin, D-lactose, maltose or melezitose. DL-Malate, oxalate and L-tartrate are assimilated and acetate, citrate and propionate are weakly assimilated, but benzoate, DL-lactate, mucate and succinate are not assimilated. Grows on L-asparagine, L-arginine, potassium nitrate, L-serine, L-threonine and L-valine, but not on L-cysteine, L-methionine or L-phenylalanine as sole nitrogen sources. Temperature range for growth is 15$37^{\circ} \mathrm{C}$. Growth occurs in the presence of $9 \%(\mathrm{w} / \mathrm{v}) \mathrm{NaCl}$.

The type strain, NRRL B-24165 ${ }^{\mathrm{T}}\left(=\mathrm{DSM} 41860^{\mathrm{T}}=\mathrm{LDDC}\right.$ $\left.6330-99^{\mathrm{T}}\right)$, was isolated from an equine placenta.

\section{Description of Streptomyces silaceus sp. nov.}

Streptomyces silaceus (si.la'ce.us. L. masc. adj. silaceus like ochre, ochre-coloured referring to the orange-yellow colour of the substrate mycelium).
Substrate mycelium is yellow to yellowish orange in colour. Aerial mycelium, where produced, on media such as yeast extract-malt extract agar (ISP 2) are white to yellowish white. No soluble pigments are produced. Spores are borne on flexuous aerial hyphae (Rectiflexibiles), are ovoid to cylindrical $(0.6-0.7 \times 0.7-0.8 \mu \mathrm{m})$ and have a smooth surface. Melanin pigments are not produced. Adenine, casein, aesculin, gelatin, hypoxanthine, starch, tyrosine, urea and xanthine are hydrolysed, but allantoin is not. Nitrate reductase is produced but phosphatase is not. Acid is produced from adonitol, cellobiose, dextrin, D-fructose, galactose, glucose, glycerol, inositol, D-lactose, maltose, mannitol, D-mannose, melibiose, methyl $\alpha$-D-glucoside, methyl $\beta$-xyloside, raffinose, salicin and D-xylose. Acid is weakly produced from trehalose. Acid is not produced from L-arabinose, dulcitol, erythritol, melezitose, L-rhamnose, sorbitol or sucrose. Grows on adonitol, cellobiose, dextrin, D-fructose, galactose, glucose, mannitol, D-mannose, melibiose, raffinose and salicin as sole carbon sources and weak growth on maltose and sucrose, but no growth on L-arabinose, inositol, inulin, D-lactose, melezitose, Lrhamnose or D-xylose. Assimilation of acetate, citrate, DLmalate and oxalate, weak assimilation of propionate and succinate, and no assimilation of benzoate, DL-lactate, 
mucate or L-tartrate. Grows on L-asparagine, L-arginine, potassium nitrate and L-threonine as sole nitrogen sources, weak growth on L-cysteine, L-histidine, L-serine and L-valine, and no growth on L-methionine or L-phenylalanine as sole carbon sources. Growth occurs in the presence of $9 \%(\mathrm{w} / \mathrm{v}) \mathrm{NaCl}$. The temperature range for growth is $15-37{ }^{\circ} \mathrm{C}$.

The type strain, NRRL B-24166 ${ }^{\mathrm{T}}\left(=\mathrm{DSM} 41861^{\mathrm{T}}=\mathrm{LDDC}\right.$ $\left.6638-99^{\mathrm{T}}\right)$, was isolated from an equine placenta.

\section{Acknowledgements}

The assistance of Professor Jean Euzéby in providing the correct etymology for the proposed species epithets and the able technical assistance of E. N. Hoekstra for physiological characterization is gratefully acknowledged. Names are necessary to report factually on available data; however, the USDA neither guarantees nor warrants the standard of the product, and the use of the name by USDA implies no approval of the product to the exclusion of others that may also be suitable.

\section{References}

Altschul, S. F., Madden, T. L., Schäffer, A. A., Zhang, J., Zhang, Z., Miller, W. \& Lipman, D. J. (1997). Gapped BLAST and PSI-BLAST: a new generation of protein database search programs. Nucleic Acids Res $\mathbf{2 5}$ 3389-3402.

Chun, J., Lee, J.-H., Jung, Y., Kim, M., Kim, S., Kim, B. K. \& Lim, Y. W. (2007). EzTaxon: a web-based tool for the identification of prokaryotes based on $16 \mathrm{~S}$ ribosomal RNA gene sequences. Int J Syst Evol Microbiol 57, 2259-2261.

Donahue, J. M. \& Williams, N. M. (2000). Emergent causes of placentitis and abortion. Vet Clin North Am Equine Pract 16, 443-456.

Donahue, J. M., Williams, N. M., Sells, S. F. \& Labeda, D. P. (2002). Crossiella equi sp. nov., isolated from equine placentas. Int J Syst Evol Microbiol 52, 2169-2173.

DSMZ (2001). Catalogue of Strains. Braunschweig: Deutsche Sammlung von Mikroorganismen und Zellkulturen.

Eck, R. V. \& Dayhoff, M. O. (1966). Atlas of Protein Sequence and Structure. National Biomedical Research Foundation, Silver Springs, Maryland.

Fitch, W. M. (1971). Towards defining the course of evolution: minimum change for a specific tree topology. Syst Zool 20, 406-416.

Giles, R. C., Donahue, J. M., Hong, C. B., Tuttle, P. A., PetritesMurphy, M. B., Poonacha, K. B., Roberts, A. W., Tramontin, R. R., Smith, B. \& Swerczek, T. W. (1993). Causes of abortion, stillbirth, and perinatal death in horses: 3,527 cases (1986-1991). J Am Vet Med Assoc 203, 1170-1175.

Gordon, R. E., Barnett, D. A., Handerhan, J. E. \& Pang, C. (1974). Nocardia coeliaca, Nocardia autotrophica, and the nocardin strain. Int J Syst Bacteriol 24, 54-63.
Hasegawa, T., Takizawa, M. \& Tanida, S. (1983). A rapid analysis for chemical grouping of aerobic actinomycetes. J Gen Appl Microbiol 29, 319-322.

Hong, C. B., Donahue, J. M., Giles, R. C., Petrites-Murphy, M. B., Poonacha, K. B., Roberts, A. W., Smith, B. J., Tamontin, R. R., Tuttle, P. A. \& Swerczek, T. W. (1993). Etiology and pathology of equine placentitis. J Vet Diagn Invest 5, 56-63.

Kim, S. B. \& Goodfellow, M. (2002). Streptomyces avermitilis sp. nov., nom. rev., a taxonomic home for the avermectin-producing streptomycetes. Int J Syst Evol Microbiol 52, 2011-2014.

Kimura, M. (1980). A simple method for estimating evolutionary rates of base substitutions through comparative studies of nucleotide sequences. J Mol Evol 16, 111-120.

Kumar, S., Tamura, K. \& Nei, M. (1993). MEGA: Molecular evolutionary genetics analysis. Pennsylvania State University, University Park, PA.

Kurup, P. V. \& Schmitt, J. A. (1973). Numerical taxonomy of Nocardia. Can J Microbiol 19, 1035-1048.

Labeda, D. P. \& Kroppenstedt, R. M. (2000). Phylogenetic analysis of Saccharothrix and related taxa: proposal for Actinosynnemataceae fam. nov. Int J Syst Evol Microbiol 50, 331-336.

Labeda, D. P., Donahue, J. M., Williams, N. M. \& Sells, S. F. (2003). Amycolatopsis kentuckyensis sp. nov., Amycolatopsis lexingtonensis sp. nov., and Amycolatopsis pretoriensis sp. nov., isolated from equine placentas. Int J Syst Evol Microbiol 53, 1601-1605.

Ludwig, W., Strunk, O., Westram, R., Richter, L., Meier, H., Yadhukumar, Buchner, A., Lai, T., Steppi, S. \& other authors (2004). ARB: a software environment for sequence data. Nucleic Acids Res 32, 1363-1371.

Nei, M. \& Kumar, S. (2000). Molecular Evolution and Phylogenetics. Oxford University Press, New York.

Pearson, W. R. \& Lipman, D. J. (1988). Improved tools for biological sequence comparison. Proc Natl Acad Sci U S A 85, 2444-2448.

Rzhetsky, A. \& Nei, M. (1992). Statistical properties of the ordinary least-squares, generalized least-squares, and minimum-evolution methods of phylogenetic inference. J Mol Evol 35, 367-375.

Saitou, N. \& Nei, M. (1987). The neighbor-joining method: a new method for reconstructing phylogenetic trees. Mol Biol Evol 4, 406426.

Shirling, E. B. \& Gottlieb, D. (1966). Methods for characterization of Streptomyces species. Int J Syst Bacteriol 16, 313-340.

Stackebrandt, E. \& Ebers, J. (2006). Taxonomic parameters revisited: tarnished gold standards. Microbiol Today 33, 152-155.

Tamura, K., Dudley, J., Nei, M. \& Kumar, S. (2007). MEGA4: Molecular evolutionary genetics analysis (MEGA) software version 4.0. Mol Biol Evol 24, 1596-1599.

Tamura, T., Ishida, Y., Otoguro, M., Hatano, K., Labeda, D. P., Price, N. P. \& Suzuki, K. I. (2008). Reclassification of Streptomyces caeruleus as a synonym of Actinoalloteichus cyanogriseus, and reclassification of Streptomyces spheroides and Streptomyces laceyi as later synonyms of Streptomyces niveus. Int J Syst Evol Microbiol 58, 2812-2814. 